\title{
Sugata Bose, His Majesty's Opponent: Subbas Chandra Bose and India's Struggle Against Empire (Cambridge: Harvard University Press, 2011).
}

Sugata Bose masterfully presents the life of Subhas Chandra Bose, whose work spread over the last decades of the British Empire, the Second World War, and whose god-like status stretched the limits of popular imagination in the subcontinent and beyond. The historian Bose, in recounting the life of his grandfather's younger brother, writes with consummate ease and élan to craft a moving, balanced, and persuasive argument to reconsider Bose as someone who was so steeped in the love of his country that nothing - not even his wartime alliances with the axis powers - tarnished this passion. Indeed, the challenge of writing such a book rested on the historian balancing his personal and academic investment in the life of a national and an international hero with the need to recover the ethical grounds of Bose's choices in the tumultuous years of the 1930s and 1940s. Sugata Bose succeeds admirably in this endeavour.

Bose achieves this balance by making two other characters constantly present in the background, Mahatma Gandhi and Emilie Schenkl, whom Bose secretly married in December 1937 (129). Though by the end of his life, Bose was a "great popular hero - the object of almost blind and uncritical adulation, on a par with Mahatma Gandhi " (7), he had begun his political career by following the Mahatma. Bose met and corresponded with the Mahatma since 1921 (45), and as a participant in Gandhi's non-cooperation, was even imprisoned (5152). However, Bose soon felt that there had to be an alternative to Gandhi's call for non-cooperation and non-violence (55). This search led Bose along a chosen path of action that did not always meet with Gandhi's approval. Indeed, the climactic episode occurred when Bose had to resign from the Presidency of the Congress, despite defeating Gandhi’s nominee in 1939 (153-163), which highlighted the stark differences that had crept between them. However, Bose maintained his admiration of Gandhi and "responded by wishing to keep personal relations above political differences, and by professing deep personal regard and love for Mahatma Gandhi” (178). For his part, Gandhi admired the rebellious son of India and acknowledged his resourcefulness in rising against the Empire (322). This steady reference to Gandhi helps the historian to contextualize Bose's actions as not devoid of ethicality but rather, while deeply influenced by Gandhi, nevertheless led Bose towards a very different path than envisioned by the Mahatma.

Emilie Schenkl forms the invisible backbone of not only Bose's life but also the book. Bose details the special relationship that Bose had with Emilie from their first meeting in 1934 (96), to recording her reaction when she heard that Bose had died in an air-crash on August 18, 1945 (304). This relationship, captured in vivid detail, mainly through Bose's letters to Emilie, displays the 
poetic, romantic, and human side of Bose, an aspect that, when missed, leads to an undermining of "a multi-faceted personality" (10). Bose and Emilie's favorite place of retreat, the Austrian town of Badgastein, serves as a calming backdrop to the otherwise adventurous life that Bose led for the cause of India's freedom. In making Gandhi and Emilie central to the narrative, Sugata Bose recovers an ethical ground to explain Bose's choices during the war. He argues that Bose's love for his country rivaled only that of Gandhi's, and it came at the cost of his love for Emilie.

The book itself is organized chronologically, closely following Bose's life through his early years, the prolonged periods of confinement, illness, exile, and political successes, including his dramatic escape from house arrest in Calcutta. In two riveting chapters, Sugata Bose details Bose's ingenious escape, his journey to Europe and then back to Asia, the formation of the Indian National Army, and its eventual failure amidst the backdrop of the global stage of the War, all of which truly demonstrate why Bose was an undisputed and resourceful leader of India (180-303). Bose ably concludes the book by providing clinching and convincing evidence of the leader's death (304-321), an exercise that lays the controversy to rest.

In such a must-read book, a quibble I have is the presentation of Bose only as an ardent nationalist. This effort is understandable, given the breadth and richness of Bose's experience in the global stage; however, it is clear that 'His Majesty's Opponent' was more than simply a nationalist. Bose's life, on the contrary, offers a critique of nationalism itself, especially when we consider yet another parallel between him and Gandhi. While Gandhi's project of nationalism began outside the borders of India, he returned home in the early $20^{\text {th }}$ century to finish it. Bose, by contrast, had to leave India in the 1940s to pursue the same passion. Clearly, between the three decades, what one witnessed was not only the downfall of an empire but also a change in the character of nationalism itself. Bose's unmatched life thus offers an alternative starting point to critically reconsider the history of Indian nationalism, a perspective that remains almost hidden in this otherwise formidable book.

Arvind Elangovan

University of Chicago

Timothy Balzer, The Information Front: The Canadian Army and News Management during the Second World War (Vancouver: University of British Columbia Press, 2011).

Referring to the quality of news reporting during the Second World War, 